Удк 330.101.1

\title{
КОНЦЕПТУАЛЬНІ ОСНОВИ ПОСТІНДУСТРІАЛЬНОГО ЕТАПУ РОЗВИТКУ ЕКОНОМІЧНОÏ СИСТЕМИ: ТЕОРЕТИЧНІ ЗАСАДИ
}

\section{CONCEPTUAL BASICS OF POSTINDUSTRIAL STAGE OF ECONOMIC SYSTEM DEVELOPMENT: THEORETIC PRINCIPLES}

\author{
Черничко Тетяна Володимирівна \\ доктор економічних наук, профресор, \\ Мукачівський державний університет \\ ORCID: https://orcid.org/0000-0002-0498-9130 \\ Козик Ірина Миколаївна \\ аспірант, \\ Мукачівський державний університет \\ ORCID: https://orcid.org/0000-0002-7113-663X \\ Chernychko Tetiana, Kozyk Iryna \\ Mukachevo State University
}

\begin{abstract}
Стаття присвячена актуальним питанням визначення теоретичних основ постіндустріального типу розвитку економічної системи. Проведено критичний аналіз позицій провідних вчених щодо сутнісних характеристик постіндустріальної економіки. Обґрунтовується, що наукові витоки теорії постіндустріального типу розвитку ґрунтуються на концептуальних положеннях теорії постіндустріального суспільства Белла. Проведено дослідження основних етапів періодизації розвитку суспільства на основі хвильової теорії Елвіна Тоффрлера. Окреслено основні риси, визначено рушійні сили та чинників фрормування, наведено характеристику третього етапу розвитку - постіндустріального суспільства. Зроблено висновок, що суспільство постіндустріального типу з'являється та розвивається не внаслідок еволюційних законів або специфічних історичних подій, а як результат впливу суспільства самого на себе.

Ключові слова: економічна система, постіндустріальний тип розвитку, теорії постіндустріального суспільства Белла, хвильова теорія Тоффрлера.
\end{abstract}

Статья посвящена актуальным вопросам изучения теоретических основ постиндустриального типа развития экономической системы. Проведено критический анализ позиций ученых относительно характеристик постиндустриальной экономики. Обосновывается, что истоки теории постиндустриального типа развития основываются на концептуальных положениях теории постиндустриального общества Белла. Проведено исследование основных этапов периодизации развития общества на основе волновой теории Элвина Тоффлера. Определены основные черты, движущие силы и фракторов формирования, предложена характеристика третьего этапа развития - постиндустриального общества. Сделан вывод, что общество постиндустриального типа появляется и развивается не в результате эволюционных законов или специфических исторических событий, а как результат влияния общества самого на себя.

Ключевые слова: экономическая система, постиндустриальный тип развития, теории постиндустриального общества Белла, волновая теория Тоффрлера.

The development of the modern economic system, regardless of the dynamics of its main indicators, initial conditions or the degree of integration into certain regional system formations, indicates the transition to a new postindustrial stage of development. The purpose of the article is to study the evolution of scientific approaches to determining the essence of the postindustrial stage of development of society, the establishment of its main driving forces and factors of formation. There are applied general scientific methods of analysis and synthesis, grouping and comparison, systemic and historical approaches. An abstract-logical method is used for theoretical generalization and formulation of conclusions. A critical analysis of the positions of leading scientists on the essential characteristics of the postindustrial economy is conducted. It is substantiated that the scientific origins of the theory of postindustrial 
type of development are based on the conceptual provisions of Bell's theory of postindustrial society, which has been developed in the West since the mid-1950s. The main features of postindustrial society, according to D. Bell, include the growing role of theoretical knowledge as a basis for scientific and technological innovation; growth of the share of production of services; formation of professional and technical class; increased attention to theoretical knowledge, strengthening the role and importance of science, focus on the future; formation of a system of meritocracy, i.e., a person's social position is determined solely by his or her intellectual potential and ability to generate new knowledge; formation of the economic theory of information on the basis of replacement of the labour theory of value by the knowledge-based theory of value. A study of the main stages of periodization of society on the basis of Toffler's wave theory is carried out. The main features are outlined, the driving forces and factors of formation are determined, the characteristic of the third stage of historical development - postindustrial society - is given. It is concluded that a society of postindustrial type appears and develops not as a result of evolutionary laws or specific historical events, but as a result of society's influence on itself.

Keywords: economic system, postindustrial type of development, Bell's theory of postindustrial society, Toffler's wave theory.

Постановка проблеми. Розвиток сучасної економічної системи, незалежно від динаміки ії̈ основних показників, вихідних умов або ступеня інтегрованості до певних регіональних системних утворень, засвідчує перехід до нового етапу розвитку - постіндустріального.

Бурхливий розвиток наукомістких галузей, посилення інтеграційних процесів та ступеня міжнародного поділу праці, зростання залежності від умов технологічного розвитку та посилення ролі знань та науки практично у всіх галузях економіки - всі ці ознаки засвідчують, що людство вже увійшло у новий етап розвитку, перейшло до третьої хвилі еволюції (за Елвіном Тофрфлером).

Структура сучасної економічної системи, її результативність та ефективність визначається ступенем залучення сучасних інноваційних, інорормаційних, комунікаційних та інших технологій. Так, можливість розвитку аграрного сектору, а, отже і можливість забезпечення продовольчої безпеки країни, визначаються ступенем залучення знань з біотехнології та генної інженерії; промисловість забезпечує можливість виготовлення висококонкурентних товарів лише за умови застосування наукоємних технологій та промислових інновацій; ссрера послуг все більше і більше залежить від застосування сучасних інформаційно-комунікаційних технологій та доступності до якісних Інтернет-послуг. Важко уявити освіту, систему охорони здоров'я, культуру та сореру гостинності без застосування сучасних гаджетів та інсрормаційних систем.

Аналіз останніх досліджень і публікацій. Теоретична основа постіндустріального суспільства закладена ще у другі половині XX ст. у працях таких науковців, як Д. Белл, А. Кумарасвамі, А. Пенті, Е. Тофффлер. Саме у цей період соціологи та економісти запропонували теорії постіндустріального суспільства та постіндустріальної економіки.

Вперше поняття «постіндустріалізм» застосованоупрацях індійського дослідника А. Кума- расвамі. На думку науковця, постіндустріалізм це стан суспільства, який настане після розпаду індустріалізму та означає «перманентну революцію», коли громади кваліфікованих ремісників, спираючись на свої «інтелектуальні та творчі сили», витісняють індустріальний капіталізм зсередини [1; 2]. Д. Белл пише: «Якщо індустріальне суспільство засноване на машинній технології, то постіндустріальне суспільство фрормується під впливом технології інтелектуальної. I якщо капітал і праця - головні структурні елементи індустріального соціуму, то інформація і знання - основа суспільства постіндустріального...» [3; 4]. О. Тоффрлер описував постіндустіалізм, як третю хвилю розвитку цивілізації [5].

Серед вітчизняних науковців дослідженням цієї проблематики займалися О. Данильян, О. Дзьобань, Ю. Зайцев, О. Коваленко, Л. Лебедева, Д. Лук'яненко, В. Лях, О. Маруховський, В. Семиноженко, А. Чухно, В. Щербина та ін.

Не дивлячись на досить широкий перелік науковців, які приділили увагу дослідженню теорії постіндустріального розвитку, ще чимало питань залишаються невирішеними. Зокрема потребує подальшого вивчення система рушійних сил та чинників фрормування нової організації економічних відносин - постіндустріального суспільства: адже нова дійсність вимагає більш поглибленої методології її дослідження.

Формулювання цілей статті (постановка завдання). Мета статті - дослідження еволюції наукових підходів до визначення сутності постіндустріальної етапу розвитку суспільства, встановлення основних його рушійних сил та чинників фрормування.

Виклад основного матеріалу дослідження. Однією з систем періодизації історичного розвитку суспільства $€$ хвильова теорія Елвіна Тофорлера. У праці «Третя хвиля» автор порівнює розвиток людської цивілізації з певними циклами, пов'язаними 3 докорін- 
ними змінами суспільних відносин. При цьому Тоффрлер застосовує алегорію хвилі: кожний наступний тип розвитку суспільства наче хвиля усуває зі свого шляху попередній.

Перша хвиля, яка почалася приблизно 10 тисяч років назад і була пов'язана з так званою сільськогосподарською або аграрною революцією, призвела до формування нового типу аграрної (доіндустріальної) цивілізації.

Характерними ознаками цієї доіндустріальної цивілізації є:

- основним засобом виробництва була земля, володіння якою визначало можливість отримання необхідних товарів;

- структура соціальних відносин мала ієрархічний характер і визначалась не можливостями, а неекономічними чинниками силою, владою, походженням, приналежністю до певних класів (верств);

- перший та другий етапи суспільного поділу праці, виділення скотарства, землеробства та ремесла;

- повільне економічне зростання.

Як зазначає Тофорлер, «...земля була основою економіки, життя, культури, сімейної структури і політики. У кожній з них життя було організовано навколо сільського поселення. У кожній з них існував простий розподіл праці та невелика кількість чітко визначених каст і класів: знать, священики, воїни, раби чи кріпаки. У всіх таких країнах влада була авторитарною. Всюди становище людини в житті визначалося фрактом його народження. І всюди в цих країнах економіка була децентралізованою, так що кожна спільнота виробляло велику частину того, що вона потребувала» [1].

Перша хвиля не в повному обсязі вичерпала свої можливості до кінця XVII сторіччя, коли в окремих країнах світу почала розгортатися промислова (індустріальна) революція і сорормувалася друга хвиля суспільних перетворень.

Потрібно зазначити, що часовий лаг розгортання другої хвилі $€$ значно коротшим, ніж першої. Це вже не тисячоріччя, а сторіччя. Цей новий процес - індустріалізація - розповсюджувався по світу нерівномірно, в залежності від ступеня розвитку суспільства, його ресурсних можливостей, налаштованості на процес змін. В окремих країнах і на сьогоднішній день переважаючими є галузі сільського господарства, а процес індустріалізації знаходить на етапі становлення.

Основними рисами другої хвилі розвитку суспільства $€$ :

- основним засобом виробництва стає промисловий капітал;
- посилення розподілу і спеціалізації праці;

- основний напрям розвитку - зростання промислового виробництва;

- зростання споживання, рівня та якості життя;

- циклічність економічного розвитку, постійне чергування криз недо- і перевиробництва;

- соціальні відносини перестали бути ієрархічними, а спираються на майнові чинники;

- швидке економічне зростання.

Тооролер зазначає, що в основі індустріальних змін закладено докорінні зміни у системи соціально-економічних відносин. Відбувся процес побудови нової ієрархії, яка ґрунтувалася на нових відносинах між власниками капіталу та найманими працівниками, зміні підходів до організації праці та оцінюванні їі результатів. «ндустріалізм - це щось більше, ніж труби, що димлять і потокові лінії. Це велика багатостороння соціальна система, що стосувалася будь-якого аспекту людського життя і яка нападала на будь-який прояв минулого, пов'язаного з Першої хвилею» [1].

Індустріальне суспільство базується на масовому виробництві, масовому розповсюдженні, масовому споживанні, масовій освіті, засобах масової інфрормації, масовому відпочинку, масовому дозвіллі. Подібні принципи розвитку суспільства знищують індивідуальність, креативність та новаторство.

Третя хвиля розвитку цивілізації - постіндустіральне суспільство - починає фрормуватися у розвинутих країнах 3 середини 50-х років XX сторіччя.

Тофрфлер не дає новій цивілізації визначення, але доводить, що вона має принципово новий характер. «Багато чого у цій виникаючій цивілізації суперечить традиційній індустріальній цивілізації. Це водночас і технічно розвинута, і анти індустріальна цивілізація. «Третя хвиля» несе із собою новий образ життя, оснований на відновних джерелах енергії, на методах виробництва, що роблять застарілими більшість фрабричних технологій, на радикально перетворених школах та корпораціях майбутнього. Така цивілізація несе з собою новий кодекс поведінки та виводить нас за межі концентрації енергії, грошових коштів і влади» [1].

Розвиток суспільства в умовах третьої хвилі визначається:

- основним засобом виробництва стають наукові знання, інфрормація;

- знижується рівень спеціалізації, і дедалі більший попит мають спеціалісти «широкого профрілю»; 
- змінюється соціальна структура суспільства - відбувається перехід від класового поділу до профресійного;

- рівень споживання передусім у високорозвинених країнах характеризується переходом від «кількості» до «якості» життя, від «суспільства масового споживання» до пошуку шляхів якісного вдосконалення умов життя людини;

- суттєво знижуються темпи економічного зростання, але воно стає більш рівномірним.

На думку Тофрфлера, «...третя хвиля несе 3 собою властивий їй новий лад життя, заснований на різноманітних відновлюваних джерелах енергії; на методах виробництва, що роблять непотрібними більшість фрабричних конвеєрів; на нових ненуклеарних родинах; на новій структурі, яку можна назвати «електронним котеджом»; на радикально змінених школах і об'єднаннях майбутнього. Цивілізація, яка виникає пише для нас нові правила поведінки і веде нас за межі стандартизації, синхронізації і централізації, за межі прагнень до накопичення енергії, грошей або влади» [1].

У постіндустріальному суспільстві, на думку Тофрфлера, інвестиції суттєво відрізняються за напрямом та об'єктом інвестування від індустріального суспільства. Перевага надається інвестиціям, спрямованим на покращення якісних характеристик засобів виробництва, на розвиток наукових розробок та впровадження їх результатів у економічну діяльність.

Тоффлер виділяє дві головні форми, які приймає постіндустріальне суспільство під час дії. По-перше, це нововведення, тобто здатність виробляти нову продукцію внаслідок інвестування науки і техніки. По-друге, це управління, здатність використовувати складні системи інорормації і комунікацій.

Значний вклад у розвиток концепції постіндустріального суспільства здійснив Д. Белл, який висунув у своїй книзі «Майбутнє постіндустріальне суспільство» (1973 рік) тезу про те, що сучасне західне суспільство вступає в нову фазу свого розвитку, що виходить за рамки індустріалізму - домінування промислового сектора в економіці і відповідною соціальною і політичної структури суспільства.

На думку Д. Белла, до основних рис постіндустріального суспільства належать:

- зростання ролі теоретичних знань, як основи науково-технічних інновацій. «Цілком очевидно, зазначає Д. Белл, - що постіндустріальне суспільство $€$ суспільством знання в двоякому сенсі: по-перше, джерелом інновацій у все більшій мірі стають дослідження і розробки; по-друге, прогрес суспільства, що вимірюється зростаючою часткою ВНП і зростаючою частиною зайнятої робочої сили, все більш однозначно визначається успіхами в області знань» [3];

- зростання частки виробництва послуг, у тому числі у ссрері охорони здоров'я, освіти, соціального обслуговування, ссрери гостинності тощо. За словами Д. Белла, «...першою і найпростішою характеристикою постіндустріального суспільства $€$ те, що більша частина робочої сили вже не зайнята в сільському господарстві та обробній промисловості, а зосереджена в сорері послуг, до якої відносяться торгівля, фрінанси, транспорт, охорона здоров'я, індустрія розваг, а також ссрери науки, освіти та управління» [3];

- фрормування профресійно-технічного класу - науковців, науково-технічних спеціалістів, професіоналів, які становлять найчисленнішу соціальну групу та $€$ «носіями знань». «По мірі зростання ролі сервісного сектору, знижується частка традиційного фрабричного пролетаріату і підвищується частка висококваліфікованих працівників. В нових умовах вони $€$ не стільки окремою категорію осіб найманої праці, скільки якісно новою соціальною частиною працівників, який може розглядатися як професійно-технічний клас» [3].

- посилена увага на теоретичні знання, посилення ролі та значення науки, орієнтація на майбутнє («...виникають нові відносини між наукою і технологією, з визначенням центрального місця теоретичних знань» [3]);

- фрормування соціального становища людини зумовлюється виключно ії̈ інтелектуальним потенціалом і здатністю генерувати нові знання;

- фрормування економічної теорії інфрормації на основі заміни трудової теорії вартості теорією цінності, заснованої на знаннях. «Якщо індустріальне суспільство засновано на машинній технології, то постіндустріальне суспільство формується під впливом технології інтелектуальної. I якщо капітал і праця головні структурні елементи індустріального соціуму, то інфрормація і знання - основа суспільства постіндустріального» [3].

Висновки. На сьогоднішній день теоретичні положення Тофрфлера і Белла, їх фрундаментальні основи, не зазнали значних змін, а процес їх оновлення відбувається лише за рахунок виявлення нового фрактичного матеріал та результатів економічного та соціального прогресу кінця XX - початку XXI сторіччя.

Суспільство постіндустріального типу з'являється та розвивається не внаслідок еволюційних законів або специфічних історичних подій, а як результат впливу суспільства самого на себе. 


\section{СПИСОК ВИКОРИСТАНИХ ДЖЕРЕЛ:}

1. Coomaraswamy, A. Essays in Post-Industrialism: A Symposium of Prophecy Concerning the Future of Society. L., 1914. 334 p.

2. Postindustrialism and the Long Arts And Crafts Movement: between Britain, India, and the United States of America. URL: https://britishartstudies.ac.uk/issues/issue-index/issue-15/postindustrialism-and-the-long-arts-andcrafts-movement

3. Белл Д. Грядущее постиндустриальное общество. Образец социального прогнозирования / Перевод с английского под редакцией В. Л. Иноземцева. Москва, 2001. URL: https://knigogid.ru/books/484415gryaduschee-postindustrialnoe-obschestvo/toread?update_page

4. Bell, D. The Year 2000 - The Trajectory of an Idea. Toward the Year 2000. Work in Progress. Boston, 1968. Pp. 22-35.

5. Тоффрлер Э. Третья волна. URL: https://gtmarket.ru/library/basis/4821/4824

6. Иноземцев В. Л. Современное постиндустриальное общество - природа, противоречия, перспективы. URL: https://litlife.club/books/57861/read?page=1

\section{REFERENCES:}

1. Coomaraswamy, A. (Ed.) (1914). Essays in Post-Industrialism: A Symposium of Prophecy Concerning the Future of Society. London, $334 \mathrm{p}$.

2. Postindustrialism and the Long Arts And Crafts Movement: between Britain, India, and the United States of America. Available at: https://britishartstudies.ac.uk/issues/issue-index/issue-15/postindustrialism-and-the-longarts-and-crafts-movement

3. Bell, D. (2001). The Coming of Post-Industrial Society: A Venture in Social Forecasting. Moscow. Available at: https://knigogid.ru/books/484415-gryaduschee-postindustrialnoe-obschestvo/toread?update_page

4. Bell, D. (1968). The Year 2000 - The Trajectory of an Idea. Toward the Year 2000. Work in Progress. Boston, pp. 22-35.

5. Toffler, A. The Third Wave. Available at: https://gtmarket.ru/library/basis/4821/4824

6. Inozemcev, V.L. (2000). Sovremennoe postindustrial'noe obshhestvo: priroda, protivorechija, perspektivy [Modern post-industrial society: nature, contradictions, prospects]. Moscow, $304 \mathrm{p}$. 